\title{
Introducing $\mathrm{C} \mathrm{A} \mathrm{L}$
}

A practical guide to writing Computer-Assisted Learning programs 
TO

JUNE, STEVE, SUE AND MAX 


\section{Introducing $\mathrm{CA}$ L}

A practical guide to writing

Computer-Assisted Learning programs

\section{KEITH HUDSON}

Writer

formerly Manager of MICRO-T

(Microcomputer training and consultancy)

Springer-Science+Business Media, B.V. 
(C) 1984 Keith Hudson

Originally published by Chapman and Hall in 1984.

Softcover reprint of the hardcover 1st edition 1984

ISBN 978-0-412-26230-2 ISBN 978-1-4899-3190-0 (eBook)

DOI 10.1007/978-1-4899-3190-0

This title is available in both hardbound and paperback editions. The paperback edition is sold subject to the condition that it shall not, by way of trade or otherwise, be lent, re-sold, hired out, or otherwise circulated without the publisher's prior consent in any form of binding or cover other than that in which it is published and without a similar condition including this condition being imposed on the subsequent purchaser.

All rights reserved. No part of this book may be reprinted, or reproduced or utilized in an $y$ form or by any electronic, mechanical or other means, now known or hereafter invented, including photocopying and recording, or in any information storage and retrieval system, without permission in writing from the Publisher.

\section{British Library Cataloguing in Publication Data}

Hudson, Keith

Introducing CAL.

1. Computer-assisted instruction

2. Electronic digital computers-Programming

I. Title

371.3'9445 LB1028.5

\section{Library of Congress Cataloging in Publication Data}

\section{Hudson, Keith, 1935-}

Introducing CAL.

Bibliography: p.

Includes index.

1. Computer-assisted instruction-Programming. I. Title.

II. Title: Introducing C.A.L.
LB1028.65. H83 1984
$371.3^{\prime} 9445$
$84-14264$ 


\section{Contents}

\section{Introduction}

1.1 Characteristics and prospects of CAL 1

1.2 A general description 3

1.3 Interacting with the computer 4

1.4 Varieties of CAL 6

1.5 Multichoice tests 6

1.6 Drill and test 6

1.7 Educational games 6

$\begin{array}{lll}1.8 \text { Simulations } & 7\end{array}$

1.9 Experimental aids 7

1.10 Idiosyncratic programs $\quad 7$

1.11 CAL more precisely $\quad 8$

1.12 Branching and linear CAL programs 9

1.13 Objections to CAL 11

1.14 The 'quiet' development of CAL from the mid-1950s 14

1.15 The reappearance of PL as CAL 17

1.16 The present resurgence of CAL 18

$1.17 \mathrm{CAL}$ and the jobs of tomorrow 20

2 Introductory techniques 23

2.1 The frame 23

2.2 The introduction-frame 23

$2.3 \mathrm{CAL}$ writers and programmers 24

2.4 Friendly programming 25

2.5 No-response frames 26

2.6 The response frame 27

2.7 Cueing the response 28

2.8 Enrichment 29

2.9 Temporary and permanent memory 30 
2.10 The test-frame 31

2.11 Cueing again 31

2.12 The link-frame 33

2.13 Prerequisite knowledge and ability of the student 36

2.14 Nature of distribution 36

2.15 Continuing the Socrates problem $\quad 37$

$\begin{array}{ll}2.16 \text { Try-it-yourself } & 37\end{array}$

2.17 A trailer on reinforcement 41

3 Reinforcement $\quad \mathbf{4 2}$

3.1 Reinforcement or reward $\quad 42$

3.2 The response and immediate reinforcement 44

3.3 Schedules of reinforcement 49

3.4 Intermittent reinforcement 51

3.5 The final test-frame $\quad 52$

3.6 Trial and error learning 53

3.7 Incorrect responses $\quad 53$

$4 \quad$ Principles of structured learning $\quad \mathbf{5 5}$

4.1 Instinctual skills and unstructured learning 56

4.2 Social skills and semi-structured learning 58

4.3 Conceptual skills and structured learning 61

5 Brain processes of learning and memory 66

$\begin{array}{lll}5.1 & \text { The neocortex } & 66\end{array}$

$\begin{array}{ll}5.2 \text { Long-term memory } & 68\end{array}$

$\begin{array}{lll}5.3 \text { Short-term memory } & 70\end{array}$

5.4 The hypothalamus: the pleasure/pain centre 72

$\begin{array}{ll}5.5 \text { A paradigm of learning and memory } & 75\end{array}$

6 The structure of the CAL Unit $\quad 79$

$\begin{array}{lll}6.1 \text { The CAL Unit } & 79\end{array}$

$\begin{array}{ll}6.2 \text { Number of frames } & 79\end{array}$

6.3 Summary of frame types $\quad 80$

6.4 The structure of a CAL Unit 80

6.5 Front-end loading 82

6.6 Even loading $\quad 82$

$\begin{array}{lll}6.7 & \text { Hybrid structures } & 83\end{array}$

7 Frame formats $\quad \mathbf{8 5}$

7.1 Authoring languages and systems $\quad 85$

$\begin{array}{ll}7.2 & \text { Frame formats } \\ 7.3 & 86\end{array}$

7.3 No-response format 86 
$\begin{array}{lll}7.4 & \text { Copy format } & 86\end{array}$

$\begin{array}{lll}7.5 & \text { Faded prompt format } & 88\end{array}$

$\begin{array}{lll}7.6 & \text { Cued format } & 88\end{array}$

$\begin{array}{lll}7.7 & \text { Two-choice format } & 88\end{array}$

$\begin{array}{ll}7.8 \text { Multiple-choice format } & 88\end{array}$

$\begin{array}{ll}7.9 \text { Matching format } & 93\end{array}$

$\begin{array}{ll}7.10 \text { Criterion format } & 93\end{array}$

$\begin{array}{ll}7.11 \text { Short-answer format } & 93\end{array}$

$\begin{array}{ll}7.12 \text { Exergue format } & 93\end{array}$

$\begin{array}{ll}7.13 \text { Mnemonic format } & 93\end{array}$

$\begin{array}{ll}7.14 \text { Incorrect responses } & 97\end{array}$

$\begin{array}{ll}7.15 \text { Experiential format } & 97\end{array}$

$\begin{array}{lr}7.16 \text { Free-range format } & 100\end{array}$

$\begin{array}{ll}7.17 \text { Check list } & 100\end{array}$

$\begin{array}{ll}7.18 \text { Examples of poor frame writing } & 100\end{array}$

$8 \quad$ Preparation, writing and testing $\quad 107$

$\begin{array}{lll}8.1 \text { Task analysis } & 107\end{array}$

$\begin{array}{ll}8.2 \text { Educational objectives } & 112\end{array}$

8.3 Unit structure and frame type distribution 112

$\begin{array}{lll}8.4 \text { Validation } & 112\end{array}$

$\begin{array}{lll}8.5 & \text { Pilot trial } & 113\end{array}$

$\begin{array}{lll}8.6 & \text { Field testing } & 114\end{array}$

$\begin{array}{lll}8.7 \text { Coding } & 114\end{array}$

9 Publishing CAL $\quad 115$

$\begin{array}{lll}9.1 \text { Documentation } & 115\end{array}$

$\begin{array}{ll}9.2 \text { Copyright } & 115\end{array}$

$\begin{array}{ll}9.3 \text { CAL publishers } & 116\end{array}$

$\begin{array}{lll}9.4 & \text { Multi-publishing } & 117\end{array}$

$\begin{array}{lll}9.5 & \text { Interactive video } & 117\end{array}$

$\begin{array}{lll}9.6 & \text { Future scenario } & 117\end{array}$

Appendix 1

$\begin{array}{ll}\text { An exemplary CAL Unit (Biology) } & 119\end{array}$

Appendix 2

$\begin{array}{ll}\text { Various CAL and CBT authoring languages } & 158\end{array}$

Appendix 3

$\begin{array}{lr}\text { Centres of CAL activity } & 159\end{array}$

$\begin{array}{lr}\text { References } & 165\end{array}$ 
viii CONTENTS

Recommended bibliography 166

$\begin{array}{lr}\text { CAL section } & 166\end{array}$

$\begin{array}{lr}\text { Brain systems section } & 167\end{array}$

$\begin{array}{ll}\text { Tomorrow's world section } & 168\end{array}$

$\begin{array}{lr}\text { Index } & 169\end{array}$ 


\section{Preface}

It is often the case - perhaps more often than not - that new ideas arrive long before there is the means to clothe and deliver them. We can think of Leonardo da Vinci's drawings of helicopters and submarines among many other examples.

Computer-Assisted Learning (CAL) is an example of an idea which has had a particularly long gestation. As I will illustrate early in the book, the principles of CAL were really first discovered by Socrates. As a formal method of teaching, the Socratic method disappeared for over two millennia until the 1950s. It was then revived in the form of Programmed Learning (PL) which resulted from the researches of B. F. Skinner at Harvard University.

Even then, PL was premature. In the 1950s and 60s, methods were devised, such as teaching machines and various sorts of PL text books, and there was a mushrooming of PL publishing at that time. For a complex of reasons economic, logistical and technical - PL also largely disappeared from the mid60 s, although it continued in a few specialized areas of teaching and industrial training. However, during the same period, PL quietly transformed itself into CAL. But the computerized form was not capable of mass dissemination until recently because personal microcomputers did not have sufficient internal memory sizes. That situation has now changed very dramatically and $128 \mathrm{~K}$ microcomputers are becoming cheap and widely available. Cheap memory chips of $256 \mathrm{~K}$ and $1024 \mathrm{~K}$ cannot be far away, either.

A considerable quantity of so-called educational software is now being written. Some CAL programs have been brilliant and inventive, but many have been of indifferent quality because they have been but bowdlerized, computerized versions of text-book material or lecture notes. Few CAL program writers appear to have paid much attention to the important features of the human learning process now being clearly identified by scientific research in several fields.

CAL, therefore, still suffers from vagueness of definition. As yet, there is still no unambiguous name for the fundamental method of teaching as exemplified by Socrates and developed by Skinner. The most accurate 
description which also precisely defines the sort of CAL discussed in this book is: self-paced, constructed-response, immediate-feedback, learning program. I have avoided the temptation to foist yet another acronym on the world but no doubt, as the whole gamut of educational software grows and clarifies, a simple name will emerge in due course.

The early iron ships were not made by traditional shipwrights but by bridge-builders. The microcomputer did not emerge from the large computer companies but from small enterprises selling products to do-it-yourself electronics enthusiasts. In the same way, it is entirely possible that teachers and other people involved in traditional training methods will not predominate in the educational software industry that is now growing apace. The field is so new, and the prospects are so enormous, that many writers of intelligence, discipline and creativity will be attracted to this exciting and satisfying activity from many other walks of life.

My original interest in CAL - in its PL form - began in the late 1950s when I read the original papers of American behavioural psychologists. I did not return to the subject until recent years, by which time my initial fascination with PL had been augmented by my studies in brain physiology and the human learning process. I have been influenced by findings from other disciplines, of course, but my principal acknowledgements are to Professor B. F. Skinner and Professor D. H. Hubel, from behavioural psychology and neurobiology respectively, both of whom have been helpful in correspondence.

I must also acknowledge my thanks to my publisher Richard Stileman, and also Claire Gooding, who were keen on the book in its first draft and midwifed it during its later stages. Finally, my thanks also to Irene Jenkins, my hardworking and versatile research assistant and to Jane Ross at Chapman and Hall.

If the book has merit I share it with those above; if the book has faults I incline my head alone.

Keith Hudson

Monkton Combe

Avon 